\title{
Science academies
}

\section{target $\mathbf{G 8}$ agenda}

In a demonstration of how international negotiations should be done, 12 national science academies have issued two joint statements to the leaders of the G8 countries, who will meet at their annual summit in Russia next month. One endorses a reinvention of the world's disease surveillance system; the other calls for a major expansion of energy research to address a looming global crisis in energy supplies.

The statements were announced on 14 June by the academies of the G8 countries plus Brazil, China, India and South Africa. They follow the first such exercise at last year's Gleneagles summit in Britain, when Britain's Royal Society coordinated joint academy statements on climate change as well as capacity building for Africa.

The academies' stronger role in international advocacy is a "new and extremely positive development”, says Martin Rees, president of the Royal Society. "It's a step towards the international scientific community having a more effective voice at the political level."

Rees believes the academies' input influenced the outcome of last year's G8, which included greater debt relief for Africa. And he hopes the string of recommendations for disease surveillance and the energy crisis from the 12 academies (see box) will translate in firm pledges from this year's G8 meeting.

The academies argue that the size of global efforts in both infectious diseases and energy sourcing are out of touch with the scale of the problems. They lament the inadequacy of the current systems of national and interna"It's tional disease surveillance, which they describe as "multicommunity". The threat of avian flu, more they argue, should be a catalyst more effective voice for investment in a more at the political level." tightly coordinated global system, that in particular would see animal and human health experts working more closely together.

Likewise, Rees says the G8 must address what he describes as serious inadequacies in funding and incentives for energy research: "In relation to the scale of the problem, the R\&D effort worldwide is unduly low."

Although the G8 and other international political meetings are important for setting agendas and funding priorities, the academies

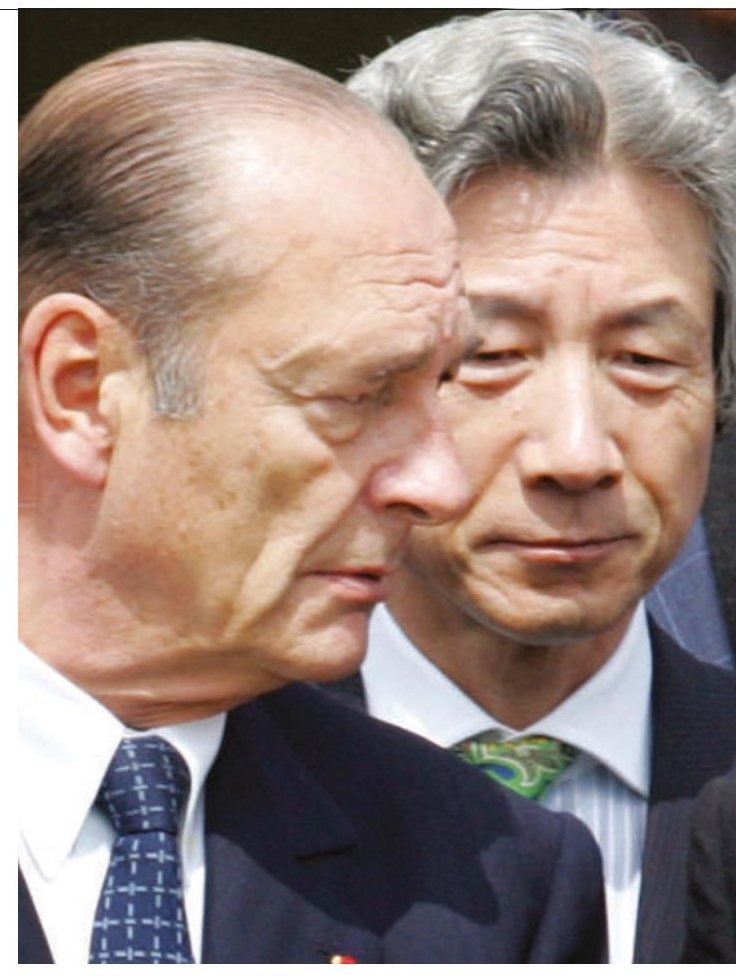

recognize their shortcomings, says André Capron, foreign secretary of France's Académie des Sciences. In particular, he criticizes the "disappointing" habit of states in neglecting to honour pledges once they get home. At an avian-flu summit in Beijing in January, for example, countries pledged US $\$ 1.9$ billion in grants and loans to a global action plan, but so far only $\$ 1$ billion has been committed, and of that just $\$ 286$ million has been spent. Donors also often insist that funds

\section{Koreans admit disguising stem-cell lines}

Federally funded US researchers were supplied with a prohibited stem-cell line, disguised as an approved line by researchers at Seoul's MizMedi hospital.

Allegations that a cell line had been switched surfaced earlier this month (see Nature 441, 680; 2006). Sung-il Roh, chairman of the board of trustees at MizMedi Women's Hospital, has now admitted to Nature that this was indeed the case.

Research with the unapproved cell line has been halted. But the incident highlights how hard it is for researchers to know what they are working with. And in this case the problem was not only scientific but political: US president George W. Bush announced in 2001 that because of ethical concerns over human embryonic stem cells, only such cell lines established before 9 August 2001 would be eligible for federally funded research. One line established by researchers at MizMedi Hospital, Miz-hES1, was created before that date, and approved by the US

National Institutes of Health (NIH). But the cell line sent out in its place, Miz-hES5, was created later.

The NIH has paid the hospital US $\$ 930,000$ since 2002 to grow,

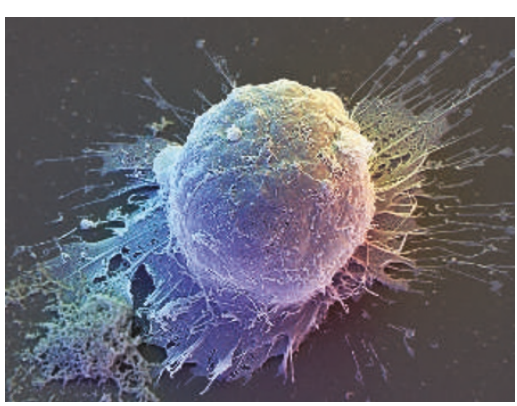

Identity crisis: stem cells all look the same.

characterize and distribute Miz-1. But Roh told Nature that in December 2003, researchers at the hospital identified a chromosomal abnormality in that line. In April
2004 they switched to Miz-5, but pretended they were shipping Miz-1.

The subterfuge came to light during the police investigation into the research fraud committed by cloning expert Woo Suk Hwang (see Nature 439, 122; 2006). The human eggs used by Hwang were harvested at MizMedi. Roh admitted in November 2005 to paying for the eggs that he passed to Hwang, despite previously claiming they were from volunteers.

Roh says he knew nothing about the stem-cell switch, and only found out from the police report. But he says: "It's a healthy line. From a research perspective, it wouldn't 
